\title{
DEVELOPMENT AND EXPERIMENTAL STUDIES OF METHODS FOR INCREASING THE STABILITY OF MATERIALS OF ACCELERATING STRUCTURES TO HIGH VACUUM ELECTRICAL DISCHARGES
}

\author{
V.A. Baturin, A.Yu. Karpenko, S.A. Yeryomin \\ Institute of Applied Physics NAS of Ukraine, Kiev, Ukraine \\ E-mail: baturin49@gmail.com
}

The experimental technique is described and the results of a study of the resistance to high vacuum electrical breakdowns of copper samples coated with thin films of titanium nitride are presented. The studies were carried out in a two-electrode system having the so-called "plane-tip" configuration. Using the method of X-ray diffractometry, we studied the effect of the structure of titanium nitride films on their efficiency as a material that reduces the probability of breakdown.

PACS: 52.80.Mg; 52.80.Vp

\section{INTRODUCTION}

In recent years, the development of compact linear accelerators with a high gradient of electric field has been actively conducted. The compact size allows to reduce financial costs for the construction and operation of the accelerator. One such project is CLIC (compact linear collider) being developed at CERN [1,2]. This project assumes that with an electric field gradient of the order of $100 \mathrm{MV} / \mathrm{m}$ the probability of breakdowns (the ratio of the number of breakdowns to the number of pulses) should not exceed $10^{-7}$. Thereby, there is a need to study various factors affecting the occurrence of high vacuum breakdowns in the materials used for the manufacture of accelerating structures of linear accelerators. One way to increase breakdown resistance is to modify the surface of the electrodes of the accelerator system.

In CERN and IAP NAS of Ukraine, collaboration is underway in this direction, and a number of experimental stands have been developed to study the resistance of materials to electrical breakdowns [3, 4]. IAP NAS of Ukraine is focused on the study of the influence of ion-beam and ion-plasma surface treatment of copper samples on the occurrence and development of high-vacuum breakdowns in a constant electric field. This paper presents some results of studies carried out according to the Memorandum of Cooperation between CERN and IAP NAS of Ukraine for the period of 20172019 , namely, the results of a study of the resistance to electrical breakdowns of the surface of copper samples with TiN film in a two-electrode "plane-tip" configuration.

\section{EXPERIMENTAL STAND}

The experiments were carried out on the stand designed in IAP NAS of Ukraine for studying of highvacuum breakdowns in a constant electric field [3]. It consists of the following elements: a vacuum chamber with a test sample pumped out by a specially developed vacuum system, a residual gas mass spectrometer, a high voltage source, and a digital multimeter for measuring breakdown current (Fig. 1).

The electrodes of the discharge gap in the vacuum chamber have the so-called "plane-tip" configuration. In this configuration the flat sample with a diameter of $11 \mathrm{~mm}$ fixed in a special holder is the cathode.

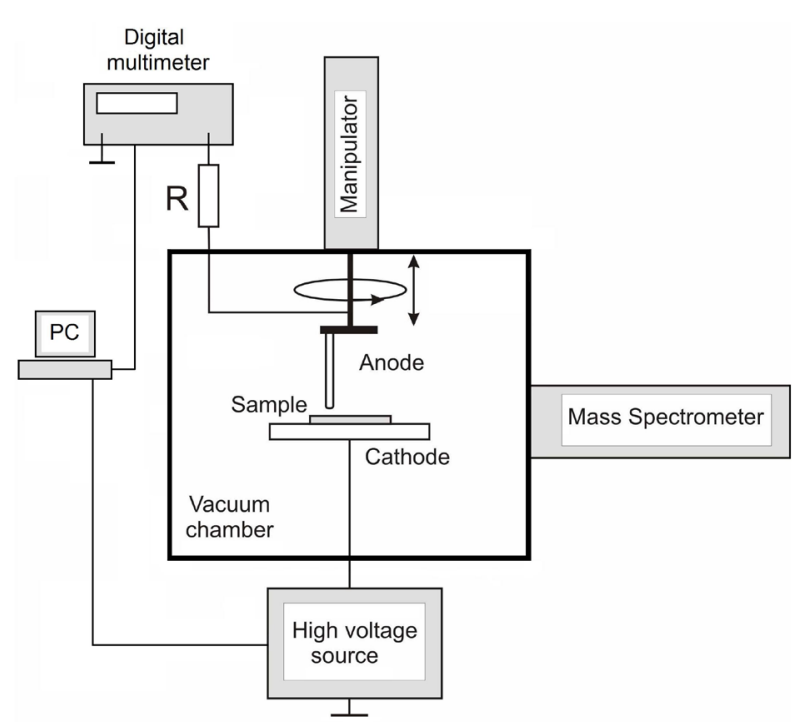

Fig. 1. Experimental stand scheme

The cathode is connected to a high voltage source of negative polarity through a high voltage ceramic input. The anode has a rod shape with a diameter of $2.5 \mathrm{~mm}$ with a rounded end. The discharge current is measured with a digital multimeter in the anode circuit through a ballast resistor $R$. The anode manipulator equipped with a micrometer screw allows the cathode-anode gap to be set with high accuracy, as well as moving the anode along the cathode plane.

The vacuum system provides vacuum at a level of $10^{-7} \mathrm{~Pa}$ in the area of the test sample. This vacuum level allows to minimize the effect of the residual gas environment on the breakdown process. The MX7304A monopole mass spectrometer is used to control the composition of the residual gas before and during the experiments. The side flange of the vacuum chamber has a window for visual observation of electrical breakdowns. The high voltage source is controlled and the current in the two-electrode gap is recorded using a computer.

\section{MEASUREMENT TECHNIQUE}

The probability of breakdowns between electrodes in a vacuum gap depends on a number of different factors, including the magnitude and type of applied voltage, electrode surface quality, vacuum level, electrode gap width, etc. In the case of direct current there are three types of violation of electric strength [5]. 
- The appearance of a more or less stable current in the two-electrode gap, which strongly depends on the voltage applied to these electrodes. These currents that flow at voltages below the breakdown are called prebreakdown or dark.

- The occurrence of periodically repeating microdischarges which are self-extinguishing and do not lead to a pronounced deterioration of electrical strength.

- The occurrence of breakdown, which is a spark discharge with a sharp drop in voltage between the electrodes, subsequently turning into an arc discharge in the electrode material vapour.

In view of the above, in order to compare the breakdown resistance of the modified sample surface with respect to the pure one, we used such criteria as: the voltage at which the pre-breakdown current occurs, the voltage at which microbreakdowns occur and the voltage of final (destructive) breakdown. Each sample was divided into two parts, one of which was exposed to surface modification, and the other was not. All experiments were conducted with a gap between the electrodes of $100 \mu \mathrm{m}$. On each part of the sample the values of the above parameters were measured at a variety of points. Subsequently, all the obtained values were averaged for each part of the sample. Since all the studied copper samples could have minimal differences in the degree of sample surface treatment and cleanliness, and also contain surface microdefects, the key in these studies are not the absolute values of breakdown voltage, but the values relative to that of the modified surface of the samples.

In our previous study on the effect of surface modification on resistance to high-vacuum breakdowns [6], it was experimentally shown that surface modification of copper samples can improve their resistance to breakdowns and reduce a pre-breakdown current depending on the method or modification. Positive results were obtained for some types of film coatings, including samples with thin films of titanium nitride, which were deposited on the surface of copper substrates. Since nowadays there is a scientific interest in titanium nitride films, for example, in accelerator technology [7 - 11], we decided to conduct additional studies, the results of which are given below.

TiN films were deposited by magnetron sputtering of a titanium target in an argon medium with the addition of nitrogen. When producing nitride films in this way, it is possible to change the phase composition, structural state, and hence the properties of the films, depending on the ion energy and nitrogen pressure. Samples of copper with low impurity content were used as the substrate. The films were deposited on one half of the sample surface, while the other one was closed. The argon pressure in the vacuum chamber was $1 \mathrm{~Pa}$, and the nitrogen pressure varied depending on the experiment in the range of $0.05 \ldots 0.5 \mathrm{~Pa}$. Thus, several dozen of copper samples were obtained with TiN films deposited on them, which had a different phase composition. The film thickness in this case varied within $60 . .200 \mu \mathrm{m}$.

Simultaneously with the deposition of films on copper samples, in each case TiN films were deposited on glass samples in order to determine the thickness of the obtained films and to take X-ray diffraction spectra. The crystal structure of TiN was studied by X-ray diffractometry using a DRON-4 computer diffractometer $(\mathrm{Cu}-$ $\mathrm{K} \alpha$ radiation with a wavelength of $0.1542 \mathrm{~nm}$ ).

\section{RESULTS AND DISCUSSIONS}

According to the experimental results, all copper samples with TiN films, which were studied for breakdown resistance, can be divided into three large groups, which have similar results in relative parameter values.

The first group of samples includes those in which the appearance of a pre-breakdown current, the start of breakdowns, and the final breakdown occurred at higher voltage values for a surface with a deposited TiN film than for pure copper (Fig. 2,a). They are also characterized by a shift in the current-voltage dependence of the pre-breakdown currents for TiN to the region of higher voltages.

In the second group of samples, for titanium nitride films pre-breakdown currents appeared at higher voltages than for pure copper, but breakdowns and final breakdown occurred at lower voltages (Fig. 2,b)

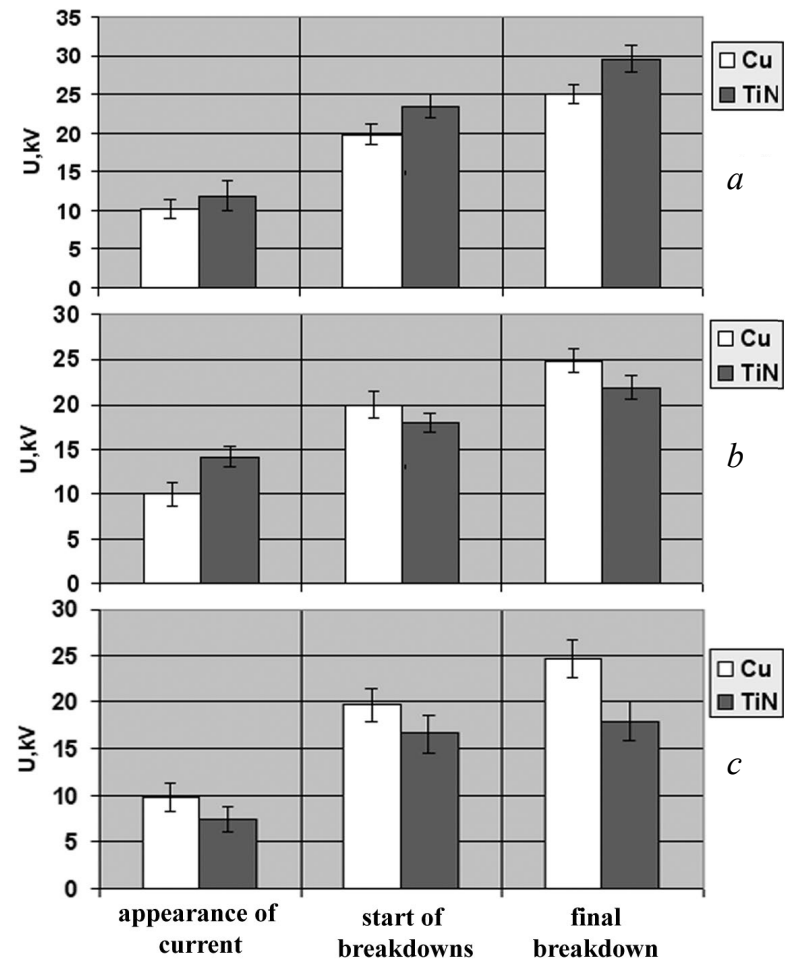

Fig. 2. Results of measurement of copper samples with TiN films for breakdown resistance. a-TiN films have better breakdown resistance with respect to copper; $b$-only the prebreakdown current of TiN appears at a higher voltage; $c$-samples with deterioration of breakdown parameters on TiN films

And finally, we assigned to the third group of samples those in which films of titanium nitride on copper led in the general case to a deterioration of all the studied parameters (Fig. 2,c).

In the general case, the thickness of titanium nitride films did not significantly affect the results of their study on breakdown resistance for different samples from the first group and could vary from 60 to $400 \mathrm{~nm}$. The study of X-ray diffraction spectra (Fig. 3) brought greater clarity to the interpretation of the results. 


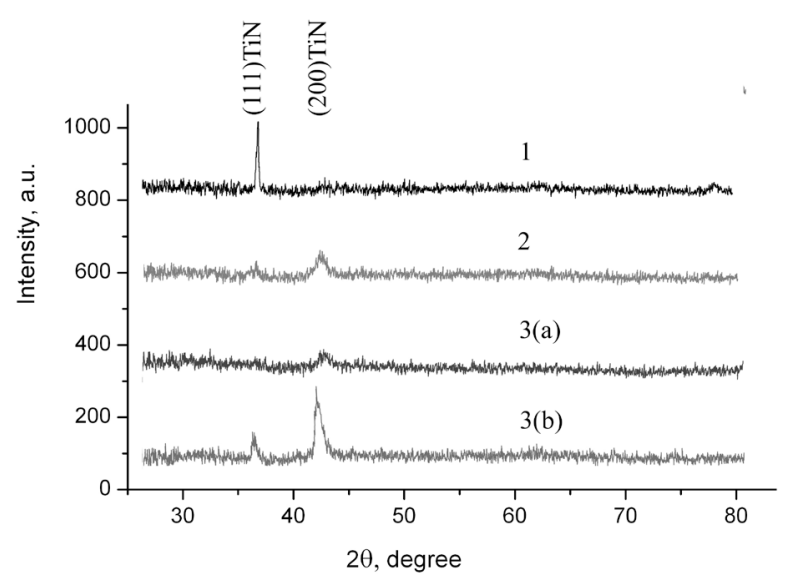

Fig. 3. Diffraction spectra of TiN films corresponding to samples with different breakdown resistance

All samples from the first group are characterized by the formation of the preferred orientation of crystallites with the (111) plane, which is parallel to the growth surface. Samples of this group have a rather high degree of texturing, which is determined by the intensity of the (111) diffraction peak (see Fig. 3, curve 1).

As can be seen from Fig. 3 on curve 2, samples from the second group lose texture and form a disoriented structural state. In this case, a decrease in the degree of texturing in the (111) plane and the formation of a different type of texture with a plane (200) are observed. For all samples of this type, the relative intensity of the $\mathrm{I}(200)$ / I(111) peaks varies from 1.38 to 1.46 .

Samples of the third group with poor parameters of titanium nitride films are divided into two subgroups. The first group (see Fig. 3, curve 3(a)) includes those in which there is no (111) diffraction peak and the texture in the (200) plane is weakly expressed and the second group (see Fig. 3, curve 3(b)) has a clear separation of the two-phase nature of the coating with its high degree of texturing with a ratio of the relative intensity $\mathrm{I}(200) / \mathrm{I}(111)$ in the order of 2.2. In this case, the thickness of titanium nitride films varied in the range of $110 \ldots 150 \mathrm{~nm}$ for all the studied samples in this group.

From the above, it can be concluded that when TiN film is used as a protective coating of accelerating structures, the dominant effect is not their thickness, but the formation of a texture in these films with a predominant orientation of (111), which reduces the probability of breakdown on such coatings. For TiN films the (111) plane corresponds to the lowest strain energy values. This effect is associated with the anisotropy of Young's modulus [12].

Such planes "line up" perpendicular to the direction of growth of the entire system as a whole, which leads to minimization of the total energy during film growth. The appearance in films of a different type of texture with a (200) plane parallel to the growth surface, which corresponds to minimizing the free surface energy for this type of crystal lattice, while decreasing the peak intensity (111), worsens the breakdown resistance of titanium nitride films. Although in this case, prebreakdown currents still occur at higher voltages compared to the copper surface without coating. A further increase in the relative intensity $\mathrm{I}(200) / \mathrm{I}(111)$ with the release of the two-phase film (see Fig. 3, curve 3(b)), as well as the disorientation of crystallites during the formation of the titanium nitride film (see Fig. 3, curve 3(a)) in both cases leads to poor resistance of such films to breakdowns.

The work was carried out in a collaboration between the National Academy of Sciences of Ukraine and the European Center for Nuclear Research (CERN) under the CLIC (Compact Linear Collider) // CLEAR project with financial support from the program "Fundamental Program of Higher Energy and Nuclear Science (International Sponsorship)” (grant № II-34-19).

\section{REFERENCES}

1. I. Wilson. The compact linear collider CLIC // Physics Reports. 2004, v. 403-404, p. 365-378.

2. R. Corsini, the CLIC Study Group. CLIC R \& D: Technology, Test Facilities and Future Plans // Nuclear Physics B - Proceedings Supplements. 2006, v. 154, № 1, p. 137-145.

3. V.A. Baturin, O.Yu. Karpenko, Ia.V. Profatilova, S.O. Pustovoitov, V.I. Miroshnichenko. The experimental setup for high voltage breakdown studies in the high vacuum // Problems of Atomic Science and Technology. Series "Plasma Electronics and New Methods of Acceleration”. 2015, № 4, p. 294-297.

4. Morten Kildemo. New spark-test device for material characterization // Nuclear Instruments and Methods in Physics Research. 2004, A530, p. 596-606.

5. I.N. Slivkov. Processy pri vysokom napryazhenii $v$ vakuume. M.: "Energoatomizdat", 1986 (in Russian).

6. V.A. Baturin, A.Yu. Karpenko, V.E. Storizhko, V.A. Shutko. Investigation of copper samples with ion-plasma treatment on the high voltage breakdowns // Problems of Atomic Science and Technology. 2018, № 4, p. 297-301.

7. Wang Dan, Yongning He and Wanzhao Cui. Secondary electron emission characteristics of TiN coatings produced by RF magnetron sputtering // Journal of Applied Physics. 2018, v. 124, 053301.

8. I. Montero, S.H. Mohamed, M. Garcia, L. Galan, and D. Raboso. Effect of surface reactions of lowenergy carbon ions on the secondary electron emission of TiN:O thin films // Journal of Applied Physics. 2007, v. 101, 113306.

9. A. Ruiz, E. Roman, P. Lozano, M. Garcia, L. Galan, I. Montero, and D. Raboso. UHV reactive evaporation growth of titanium nitride thin films, looking for multipactor effect suppression in space applications // Vacuum. 2007, v. 81, p. 1493-1497.

10. W. Kaabi, A. Variola, G. Keppel, V. Palmieri, A. Brinkmann, and I. Montero. Titanium nitride coating as a multipactor suppressor // Proceedings of IPAC'10, Kyoto, Japan (2010), p. 2887-2889.

11. H. Xu, M.A. Shapiro, and R.J. Temkin. Measurement of internal dark current in a $17 \mathrm{GHz}$, high gradient accelerator structure // Physical Review Accelerators and Beams. 2019, v. 22, p. 021002.

12.D.R. McKenzie, Y. Yin, W.D. McFall, and N.H. Hoang. The orientation dependence of elastic strain energy in cubic crystals and its application to the preferred orientation in titanium nitride thin films // Journal of Physics: Condensed Matter. 1996, v. 8, № 32, p. 5883-5890.

Article received 30.09.2019 
РАЗРАБОТКА И ЭКСПЕРИМЕНТАЛЬНЫЕ ИССЛЕДОВАНИЯ МЕТОДОВ ПОВЫШЕНИЯ УСТОЙЧИВОСТИ МАТЕРИАЛОВ УСКОРИТЕЛЬНЫХ СТРУКТУР К ВЫСОКОВАКУУМНЫМ ЭЛЕКТРИЧЕСКИМ РАЗРЯДАМ

\section{В.А. Батурин, А.Ю. Карпенко, С.А. Еремин}

Описана методика эксперимента и представлены результаты исследования на устойчивость к высоковакуумным электрическим пробоям медных образцов с нанесенными на них тонкими пленками нитрида титана. Исследования проводились в двухэлектродной системе, имеющей так называемую конфигурацию «плоскость-острие». Методом рентгеновской дифрактометрии изучено влияние структуры пленок нитрида титана на их эффективность использования в качестве материала, уменьшающего вероятность пробоя.

\section{РОЗРОБКА ТА ЕКСПЕРИМЕНТАЛЬНІ ДОСЛІДЖЕННЯ МЕТОДІВ ПІДВИЩЕННЯ СТІЙКОСТІ МАТЕРІАЛІВ ПРИСКОРЮВАЛЬНИХ СТРУКТУР ДО ВИСОКОВАКУУМНИХ ЕЛЕКТРИЧНИХ РОЗРЯДІВ}

\section{В.А. Батурін, О.Ю. Карпенко, С.О. Срьомін}

Описано методику експерименту та представлено результати дослідження на стійкість до високовакуумних електричних пробоїв мідних зразків з нанесеними на них тонкими плівками нітриду титану. Дослідження проводилися в двоелектродній системі, що має так звану конфігурацію «площина-вістря». Методом рентгенівської дифрактометрії вивчено вплив структури плівок нітриду титану на їхню ефективність використання в якості матеріалу, що зменшує ймовірність пробою. 